\title{
Regional vis-à-vis universal institution for the protection of human rights with special reference to Asia
}

\author{
Sanjay Kumar Yadav \\ National Law Institute University, Bhopal, Kerwa Dam Road, Bhopal, M.P., India \\ E-mail address: sanjay_nliu@rediffmail.com
}

\begin{abstract}
Regional institution for the protection of human rights was born in order to overcome the weaknesses of universal institution for the protection of human rights. Regional institutions not only protected the human rights of the people in a effective manner but also give the rights to the individual to move against his own State for the violation of human rights. Regional institution also provide remedy to the individual when he does not get remedy from the national system for the protection of human rights. In Asia there is no regional institution for the protection of human rights. For effective protection and enforcement of human rights there is need to establish a regional institution in Asia.
\end{abstract}

Keywords: Human rights; regional; universal; individual; civil and political rights; social; cultural and economic rights; charter; convention; covenant

\section{INTRODUCTION}

Human Rights concepts finds expanded expression and constantly covers new areas as human society continues to evolve into higher levels of development. The concepts of human rights moves very fast in comparison to static law and domestic laws take some time to assimilate these changes, therefore remedies are not available in domestic laws in various cases of violation of human rights. So in order to fill the vacuum, there is need to create a parallel system along with the existing machinery or to give extra power to the existing machinery, arises. So that they can give effect to the changes that comes in the field of human rights. If the State fails to recognize the changes which comes in the field of human rights, it forces the individual to seek the help of an external forum which not only recognizes these changes but it may also enforces these changes which comes in the field of human rights.

In most of the cases where sovereign is itself involved in the violation of human rights like mass killing, genocide, forced disappearance etc., is very reluctant to take action for the protection of human rights, even if remedy is available under the domestic take no action for the protection of human rights and individual does not get any justice from existing national machinery for the protection of human rights. In such a situation question arises how does a individual should take action against his own State in order to protect his human rights? For this he needs an effective international forum to move against his own State, which will take necessary steps for the protection of human rights. 
With the establishments of United Nations, the recognition and the realization for the protection and promotion of human rights and fundamental freedoms is deemed necessary for the maintenance of peace and security. In 1966, the General Assembly adopted two Covenant which recognized the inherent dignity, equality and inalienable rights of all human beings. These rights have been regarded as the foundation of freedom, justice and peace in the world. The recognition and incorporation of rights in international documents itself is not enough, what the system is need is the effective implementation of the rights provided therein.

Regional institution are born in order to cover the weakness of universal institution for the protection of human rights. Regional institution is an effective forum for the protection of human rights in cases where State itself involve in violation of human rights or when individual does not get any remedy from the national institutions for the protection of human rights. In Asia there is no regional instrument for the protection of human rights. Even after the presence of UNO, there is violation of human rights in cases where sovereign itself involve in the violation of human rights or when no remedy is available under the domestic law. There is need to form the regional institution for the effective protection of human rights in Asia. But the regional conditions of Asia is different from other regions and reason for the rise of regionalism in Europe and other regions was different from the present conditions of Asia.

\section{CRITICAL EVALUATION OF UNO AS AN INSTITUTION FOR THE PROTECTION OF HUMAN RIGHTS}

The United Nations was established on October 24, 1945. The world had seen the devastating world war and did not want another. The UN's charter was based on this very hope; "We the peoples of the United Nations determined to save succeeding generations from the scourge of war". There have been unqualified failures of the UN in troubled placed as Somalia, Haiti, Rwanda, Bosnia, Afghanistan. During the Gulf war it provided big leaf of legitimacy for the military action by USA. In many places, it has just stood by and watched people's sufferings in Iraq, Kurds, Afghanistan, Sudan and Palestine. The UN fined itself helpless in resolving conflicts. Many places in the world have on going wars with little chance of being resolved.

\section{1. Drawbacks in UN Charter}

\section{1. 1. Principle of non-use of force}

The Charter under Article 2, para 4 stipulates that all member shall refrain in their international relations from the use of force or threat of force against the territorial integrity or political independence of any state or in any other manner not consistent with the purpose of United Nations.

The principle of non use of force being repeatedly violated by the states in all part of the world e.g. China invasion on Tibet, action against Iraq by joint forces, NATO bombing on Kosovo, use of forces itself amount to violation of human rights. Because during the use of force thousand of innocent peoples dies and wounded.

\section{1. 2. Principle of non-intervention in domestic matters of a State}

Article 2, para 7 of the Charter lays down that the United Nations shall not intervene in matters which are essentially with in the domestic jurisdiction of any state or compel any member to submit such matters to settlement by the United Nations. But UN can intervene if domestic matter is of such a nature that it may cause threat to international peace or security. No where explain that what comes under the definition of domestic matter. It may open the 
passage for the powerful nations to interfere into the domestic matter of other countries e.g. USA by misusing this particular provision and interfere in the politics of various countries of the world.

\section{1. 3. Veto power}

Article 27, para 3 of UN Charter stipulates that decision on non-procedural matters shall be taken on a votes of nine members of Security Council including the concurring votes of the permanent members. It means that the Council can take no decision on such matters if any permanent member gives a dissenting vote. This power of permanent member is known as veto power. The result is that the Council could not resolve many international problems mainly because they are related to the five permanent members or their client States. So no action can be taken against them in case of violation of human rights by big five world powers. Violation of human rights is very ramped by the big five world powers, Tibet, Chechnya, Ukraine, Afghanistan are example of it.

\section{1. 4. Measures for implementation of Human rights}

The human rights expression first time appears in the UN Charter but it did not define clearly what comes under the definition of the human rights. The Universal Declaration of Human rights comes in the year 1948, which define what comes under the definition of human rights. In order to give them binding effect UN adopted two Covenant, International Covenant on Civil and Political rights 1966, and International Covenant on Economic, Social and Cultural rights, 1966. Although implementation machinery also envisaged there in, violation of human rights continued to take place in a large scale in most of the countries of the world. The decision of Human rights Committee and Human rights Commission while dealing with the cases of violation of human rights is not binding on the State. Individual complaint mechanism is provided under the optional protocol of the International Covenant on Civil and Political rights 1966 and not mandatory. The international justice system is also defective, individual have no access to International Court of justice(ICJ). The decision of ICJ is passed through the veto of permanent members of Security Council. It means that the decision of ICJ cannot be enforced against the permanent members of Security Council. In the case of Nicaragua v. United States of America (1986), USA not only used veto power against the decision of ICJ against it enforcement by the Security Council, but also challenge personal integrity of the judges particularly Soviet and Polish judges and expressed its doubts about the future of the world court itself.

The UN is not an effective organization for the protection of human rights because of its inherent drawbacks. The credit of developing human rights jurisprudence goes to UNO. There is requirement of structural and functional amendment to gain its neutrality which will help this organization for effective implementation of human rights on world plain.

\section{REGIONALISM WITH SPECIAL REFERENCE TO HUMAN RIGHTS}

Regional arrangements are a natural growth of international co-operation. Universal organizations sometimes ignore matter confined to particular region. Universal organization is too ambitious and cannot command the allegiance necessary to fulfill its objections in a world still divided by national sovereignty. 
At the other end of the spectrum are those who are of view that regional agencies weaken the effectiveness of the UN and undermine the principle of collective security. But such a view is not correct there are provisions in the covenant of the League of Nations and UN charter which favor the establishment of regional arrangement for the protection of human rights. The Vienna conference on human rights in 1993 stated in the declaration that "Regional arrangements play a fundamental role in promoting human rights. They should reinforce universal human rights standard, as contained in international human rights and their protection". The General Assembly of UN at it 49 session by adopting resolution 49/189 reaffirmed that regional arrangement play a fundamental role in promoting and protecting human rights and should reinforce universal human rights standard as contained in international human rights instrument.

European Convention on human rights on 1950 is the first regional arrangement for the protection of human rights. The example of European model was successfully emulated by American Convention on human rights in 1969. It has been rightly said that the issues are regionalism verses universalism but regionalism with in universalism. Third regional development was seen in the form of African Charter also known as Banjul Charter on 1981. The regional institution which was formed for the protection of human rights after the European Convention of human rights followed the European model according to the social, political, economic and cultural conditions their region.

Regional conventions for the protection of human rights covers the weakness of UNO in the following ways;

(a) Under the regional convention for the protection of human rights all member nation are treated equally and no one is given special status or protection in the convention.

(b) The regional convention provided effective machinery for the protection of human rights.

(c) Individual can filed complaint against his own state in Human rights court, for the violation of human rights.

(d) The decision of human rights court is binding on contracting party, which is lacking in International Covenant on Civil and Political Rights 1966.

(e) If the domestic law fail t provide remedy, the remedy ought to be available under the convention, which is the unique feature of regional convention of human rights.

(f) It also provides remedy when human rights of people of one nation is violated by other nation.

(g) Regional institution are small organization fully devoted toward the protection of human rights in that region as compare to UNO a large organization with multiple activities in their hand.

But one thing which required to be paid attention is that regional forum for the protection of human rights never acts as alternative of domestic forum. They provide remedy only when remedy is not available under the domestic system for the protection of human rights. They are working in consonance with the other international institutions and they do not try to override the existing international institution for the protection of human rights.

Regionalism has obvious some advantage over universalism:

(a) A smaller organization which is restricted geographically can easily cope with the common problem more effectively than a world organization. 
(b) Another advantage are that UNO has become complex and is overburdened with manifold activities, therefore regional organization specially devoted to human rights would be to deal with human rights issues.

(c) Another advantages is homogenous regions having similar political system and having common or almost similar levels of economic development having a common historical background will have very little ideological differences as compared to universal organizations embracing countries from various region of the world having different political and economic system and divergent ideologies.

(d) Public opinion would also have more influence under the regional system than on the international plane.

(e) The regional organization is likely to decentralize its activities and avoid confusion.

(f) They are more readily available for the protection of human rights.

\section{NEED FOR REGIONAL INSTITUTION FOR THE PROTECTION OF HUMAN RIGHTS IN ASIA}

In Asia in most of the cases where sovereign itself involves and responsible for violation of human rights or when people are not getting justice from the existing judicial system of the State and one State violates the human rights of the people of other State remain not redressed due to lack of any effective international forum in Asia. Most of nations of Asia want to keep the matters of violation of human rights out of reach of international forum. In those cases where sovereign itself involved in the violation of human rights take no steps to protect the human rights of the victims and most of the time act as a mere spectator. The State use national machinery like Human Rights Commission or Inquiry Commission in order to divert the international attention and these bodies does not have sufficient power to take action against the State. UNO is also taking very less interest in solving the matters of violation of human rights in Asia, the violation of human rights in Tibet, Kashmir, Iraq, Syria are example of it. UNO is dominated by the powerful countries of the world. The powerful countries are behind most of the conflicts in Asia and they interfere in the politics of most of the countries of Asia.

\section{CONCLUSIONS}

Regional institution is an effective forum for the protection of human rights in comparison of universal organization. In Asia there is need to established regional organization for the protection of human rights in a effective manner. Regional organization for the protection of human rights give rights to the individual to move against his own State in case State itself involve in the violation of human rights and do not take effective step for the protection of human rights. Regional organization also provide remedy to the individual when he does not get any remedy from the domestic law for the violation of human rights. Regional organization also protect the human rights when the human rights of people of one State is violated by other State. On the other hand there is need to remove the functional and structural weakness of the UNO for the advancement of human rights jurisprudence and there is need of coordination among the UNO, and regional institutions and national machinery for the effective protection 
of human rights. They should try to complement and supplement each other in the protection of human rights.

\section{References}

[1] Bowett D. M., The law of international institution $5^{\text {th }}$ Edition, 1997.

[2] Agarwal H. O., Human Rights, $3^{\text {rd }}$ edition, 2000.

[3] Agarwal H. O., International law and Human Rights $5^{\text {th }}$ Edition, 1999.

[4] Anand R. P., International law and Regionalism 6 ${ }^{\text {th }}$ Edition, 2000.

[5] Grodsped Stephen, The nature and function of International organization $4^{\text {th }}$ Edition, 1983.

[6] Kapoor S.K., Human Rights under International Law, $1^{\text {st }}$ Edition, 1999.

[7] Chandra U., Human Rights, $3^{\text {rd }}$ Edition, 2000.

[8] Human Rights Watch Reports available on: www.hrw.org

[9] UN Charter, Universal Declaration of Human rights, International Covenant on Civil and Political rights 1966, and International Covenant on Economic, Social and Cultural rights, 1966.

[10] European Convention on Human Rights 1950, American Convention on human rights in 1969 and African Charter, 1981. 